\title{
Nonvoted Ballots and Discrimination in Florida
}

John R. Lott, Jr.

\begin{abstract}
The report by the U.S. Commission on Civil Rights on the presidential vote in Florida during the 2000 general election presents two types of empirical evidence that African Americans were systematically denied the right to vote. To reach their conclusion that discrimination had occurred, the commission examined the impact of race on spoiled (or nonvoted) ballot rates as well as the impact of race on the exclusion of voters from eligibility lists because of past felony criminal records. Using extremely detailed cross-sectional data collected by USA Today and less detailed panel data, I find that to the extent that these types of regressions measure discrimination, it is African-American Republicans who were harmed. Indeed, the nonvoted ballot rate for white Republicans is higher than for white or African-American Democrats. The data also indicate that nonvoted ballot rates are highest in those counties where Democrats are the election supervisors.
\end{abstract}

\section{INTRODUCTION}

Disturbing claims of discrimination were raised after the 2000 presidential election. African-American ballots were said to be "spoiled"- that is, not counted because they showed either no vote for president or multiple votes-at higher rates than the ballots of other groups. The chair of the U.S. Civil Rights Commission called for a criminal investigation (Hume 2001). The Reverend Jesse Jackson was

JOHN R. LOTT, JR., is Resident Scholar, American Enterprise Institute. My interest in this question originated from work that I originally performed at the request of the minority members of the U.S. Commission on Civil Rights. I also served as an expert for USA Today in evaluating the precinct-level data that the newspaper put together, and they provided most of the data upon which this paper is based. I received no compensation for any of this work.

Journal of Legal Studies 32 (January 2003)

(C) 2003 by The University of Chicago. All rights reserved. 0047-2530/2003/3201-0007\$01.50 
not alone in charging "a clear pattern of suppressing the votes of African Americans" (Chafets 2001, p. 39).

The U.S. Commission on Civil Rights report (2001) on the 2000 presidential vote in Florida served as a main focus of these claims and presented two types of empirical evidence that African Americans were denied the right to vote. The report concluded that " $[t]$ he Voting Rights Act prohibits both intentional discrimination and 'results' discrimination. It is within the jurisdictional province of the Justice Department to pursue and a court of competent jurisdiction to decide whether the facts prove or disprove illegal discrimination under either standard" (U.S. Commission on Civil Rights 2001, chap. 1). To reach their conclusion that discrimination had occurred, the commission examined the impact of race on spoiled (or nonvoted) ballot rates as well as the impact of race on the exclusion of voters from eligibility lists because of past felony criminal records. The commission relied on empirical estimates of nonvoted ballots derived solely from cross-county regressions or correlations using data from 2000 alone. The evidence that African Americans are erroneously placed on the ineligible list at higher rates than other racial groups is based on a simple comparison of means.

My examination of the data here demonstrates three things:

1. Cross-sectional precinct-level data that were compiled by a group of newspapers led by USA Today allow for a much more detailed examination and indeed imply that precincts with more African-American voters have higher rates of nonvoted ballots. But if spoiled ballots do indicate disenfranchisement, then the new data show that, by a dramatic margin, the group most victimized in the Florida voting was AfricanAmerican Republicans. The new finding is stunning: African-American Republicans who voted in Florida were in excess of 50 times more likely than the average African American to have had a ballot declared invalid because it was spoiled. (The Appendix uses the commission's method and data for determining whether there is "a direct correlation between race and having one's vote discounted as a spoiled ballot" (U.S. Commission on Civil Rights 2001, chap. 1), but the results are quite sensitive to the specification used. Using that method, it is simply not possible to distinguish whether the higher spoilage rate among African Americans is a result of their being African American, being in counties with Democratic election supervisors, or being in counties with African-American election supervisors.)

2. Discussions of the nonvoted ballot rates by the commission and 
others fail to account for which counties had high rates of nonvoted ballots in the past. Once these past rates are accounted for, additional increases in the percentage of voters in a county who are African American are not related to changes in the rate that ballots are not voted. While the difference is not statistically significant, the ballot nonvoting rate is slightly more positively related to the share of white voters than African-American voters.

3. The report's own evidence that African Americans are erroneously included on the ineligible list at higher rates than other racial groups actually shows the opposite of what the commission thinks that it does. The evidence that African Americans win a greater share of successful appeals does not account for the fact that African Americans make up an even much greater share of the list of ineligible voters to begin with. In fact, the rate at which whites are removed from the list because they were incorrectly included to begin with is almost twice the rate of African Americans.

The evidence thus indicates that even if the commission is correct on the law (and there is some debate on that), ${ }^{1}$ it is difficult to accept the commission's conclusion that discrimination was unintentional and surely not intentional, unless one believes that black Democratic county election supervisors were responsible for higher nonvoted ballot rates by African-American voters. The following sections will first evaluate the data on nonvoted ballots and then turn to the data on African Americans being erroneously excluded from voting because of felony criminal records.

\section{REEXAMINING THE SIMPLE CORRELATIONS AND MEANS}

Ideally, any analysis of nonvoted ballots and race would directly link whether individuals in a particular group actually had nonvoted ballots. Lacking that direct link, the U.S. Commission on Civil Rights (2001) attempts to see whether counties or precincts with a higher percentage of African Americans have a higher percentage of nonvoted ballots. The report interprets evidence linking a higher percentage of African Americans with a higher percentage of nonvoted ballots as showing that what-

1. For this discussion, see the report by Commissioners Abigail Thernstrom and Russell G. Redenbaugh (Thernstrom and Redenbaugh 2001, p. 7). 
ever is causing ballots to be nonvoted affects some fixed percentage of African Americans who go to the polls.

The report provides many scatter plots to illustrate this correlation across precincts and counties. The problem is that all the evidence provided is based on purely cross-sectional evidence. Yet purely cross-sectional evidence suffers from well-known weaknesses in not being able to account for other factors that may explain the relationship between race and nonvoted ballots.

The simplest way to account for these other factors is to examine whether certain counties had high levels of nonvoted ballots even before they had high levels of African Americans. Thus, we examine counties over time and compare the change in the racial composition of voters with the change in nonvoted ballots. If African Americans disproportionately account for nonvoted ballots, the percentage of African Americans and nonvoted ballots should continue to hold across elections: counties with the largest increase in the percentage of voters who are African American should also have the largest increase in the percentage of nonvoted ballots.

To examine this, I compared the change in county ballot spoilage rates and the change in the share of voters in those elections who were of different races between the presidential elections in 1996 and 2000. The results are shown in Figures 1-4. Generally, it is difficult to see much of any relationship. If indeed there is one, it turns out to be the opposite of that implied by the commission's report: there is a very small negative correlation between increases in the percentage of voters who are African-American and spoilage rates (a correlation of -4 percent). And an increase in the share of white voters is associated with an increase in the nonvoted ballot rate, although none of these very simple relationships are statistically significant. ${ }^{2}$ Using data from the Election Data Services $^{3}$ on the type of voting equipment used in different counties, it is also possible to break down these figures on the basis of those counties that used the same voting machines in both the 1996 and 2000 elections. Doing so produces a set a graphs that is very similar to Figures 1-4 (see Appendix Figures A1-A6).

2. The correlation between the change in nonvoted ballots and the share of voters who are white is .09 , the same correlation for Hispanics is .03, and the correlation for "other" (neither white nor African American) is -.17.

3. Election Data Services, 1401 K Street, N.W., Suite 500, Washington, DC 200053417. 


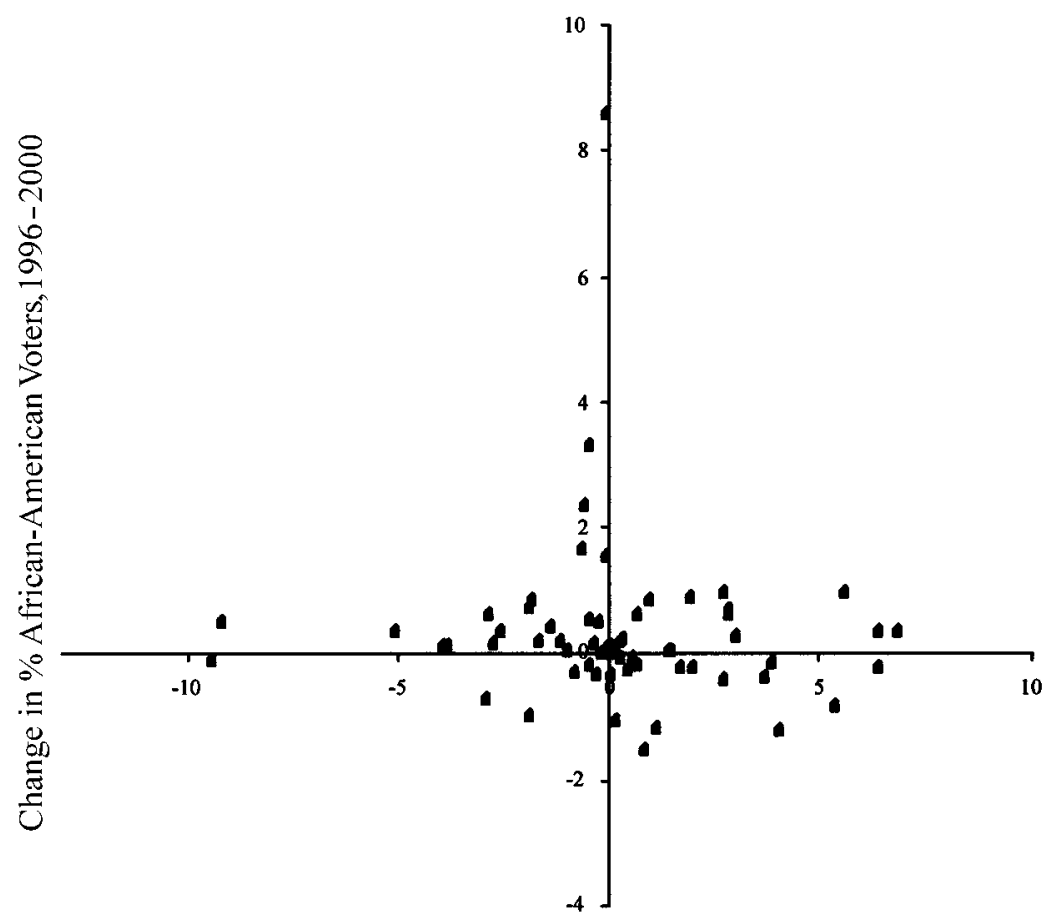

Change in \% Nonvoted Ballots, 1996-2000

Figure 1. African Americans and nonvoted ballot rate

\section{ANALYZING THE PURELY CROSS-SECTIONAL PRECINCT-LEVEL DATA}

USA Today, the Miami Herald, Florida Today, and five other newspapers undertook a massive operation to identify nonvoted ballots in each precinct in Florida for the 2000 presidential election. ${ }^{4}$ They put together a very rich cross-sectional data set. Besides the number of African Americans, whites, Hispanics, and others who voted in each precinct, the papers further broke down this relationship by political affiliation so that it is possible to know, for example, the number of African-American Republicans and Democrats who voted by precinct. They also collected information on ballot and machine type, whether the ballots were

4. The original U.S. Commission on Civil Rights (2001) report claimed to have examined precinct-level data for Miami-Dade, Duval, and Palm Beach counties, but no regressions were reported. 
186 / THE JOURNAL OF LEGAL STUdies / VOLUME 32 (1) / JANUARY 2003

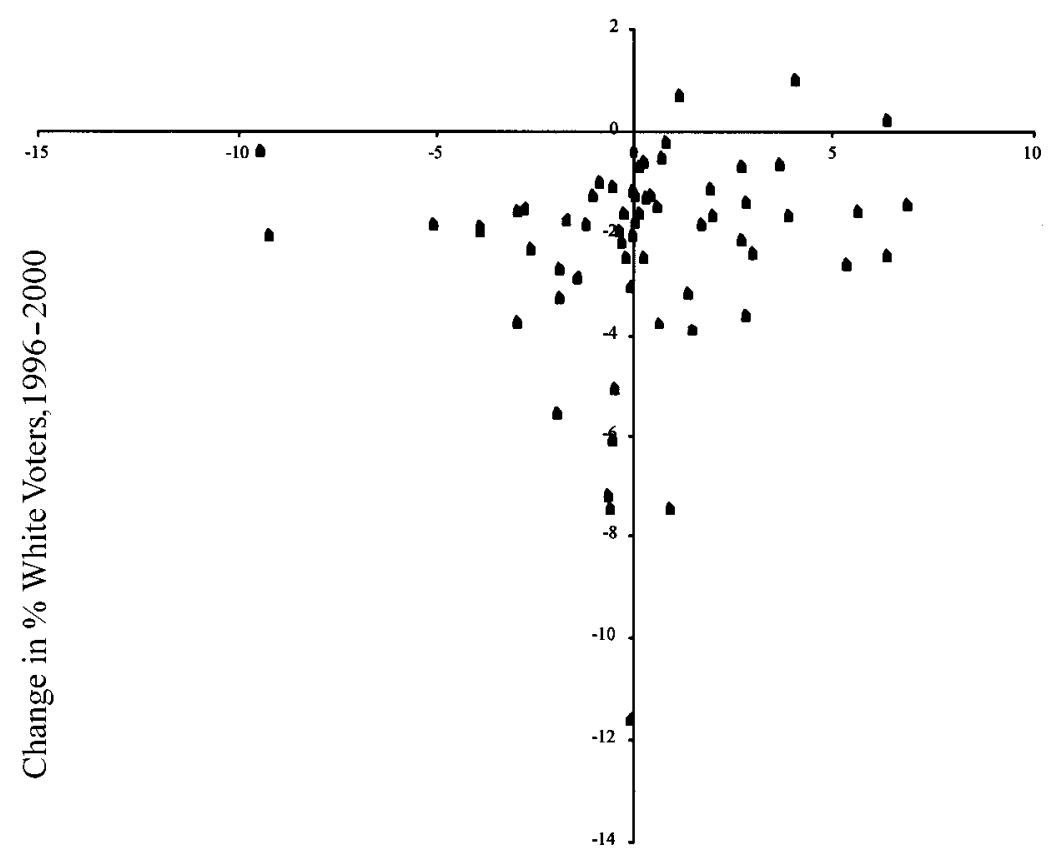

Change in \% Nonvoted Ballots, 1996-2000

Figure 2. Whites and nonvoted ballot rate

counted centrally or at the precinct, as well as detailed census data on educational obtainment, household income, and age.

The regression estimates presented here are Poisson regressions because of the obvious count nature of these data. Appendix Figure A7 illustrates how the distribution of nonvoted ballots (for under- and overvotes as well as for the total) exhibits the classic shape seen for Poisson distributions. The coefficients are reported as incident rate ratios, so coefficient values greater than one indicate the percentage increase in uncounted votes from a 1-unit increase in exogenous variable, while values less than one indicate the opposite. For example, the coefficient for Democratic county election supervisors in Table 1 , column 1 , is 1.129 , and it implies that even after accounting for all the other factors from voting methods and machines to demographics, having a Democratic supervisor is associated with a nonvoted ballot rate that is higher by about 13 percent. 


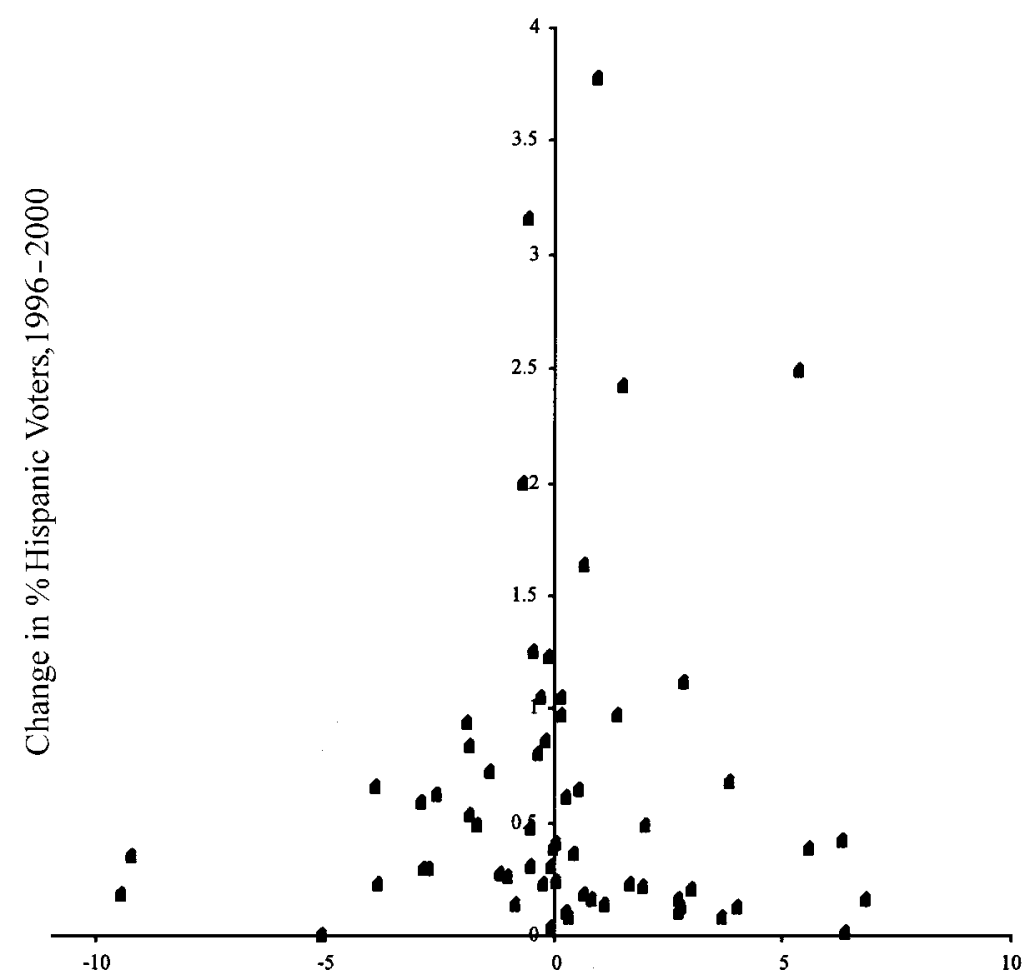

Change in \% Nonvoted Ballots, 1996-2000

Figure 3. Hispanics and nonvoted ballot rate

The regressions use all the data supplied to me on whether votes were counted centrally or at the precinct, the different types of voting machines and ballots used, income categories from $\$ 15,000$ to $\$ 25,000$ and up through over $\$ 500,000$, and the level of residents' schooling from high school not completed through college graduate. Additional variables were the number of males, number of females, number of absentee ballots, number of new voters, mean age, and number of people over 65. I have also combined these data with information that I had previous put together on the political affiliation and race of county election supervisors.

Even to the extent that a relationship exists between race and nonvoted ballot rates, the effect is small. Column 2 in Table 1, which uses 
188 / THE JOURNAL OF LEGAL STUdies / VOLUME 32 (1) / JANUARY 2003

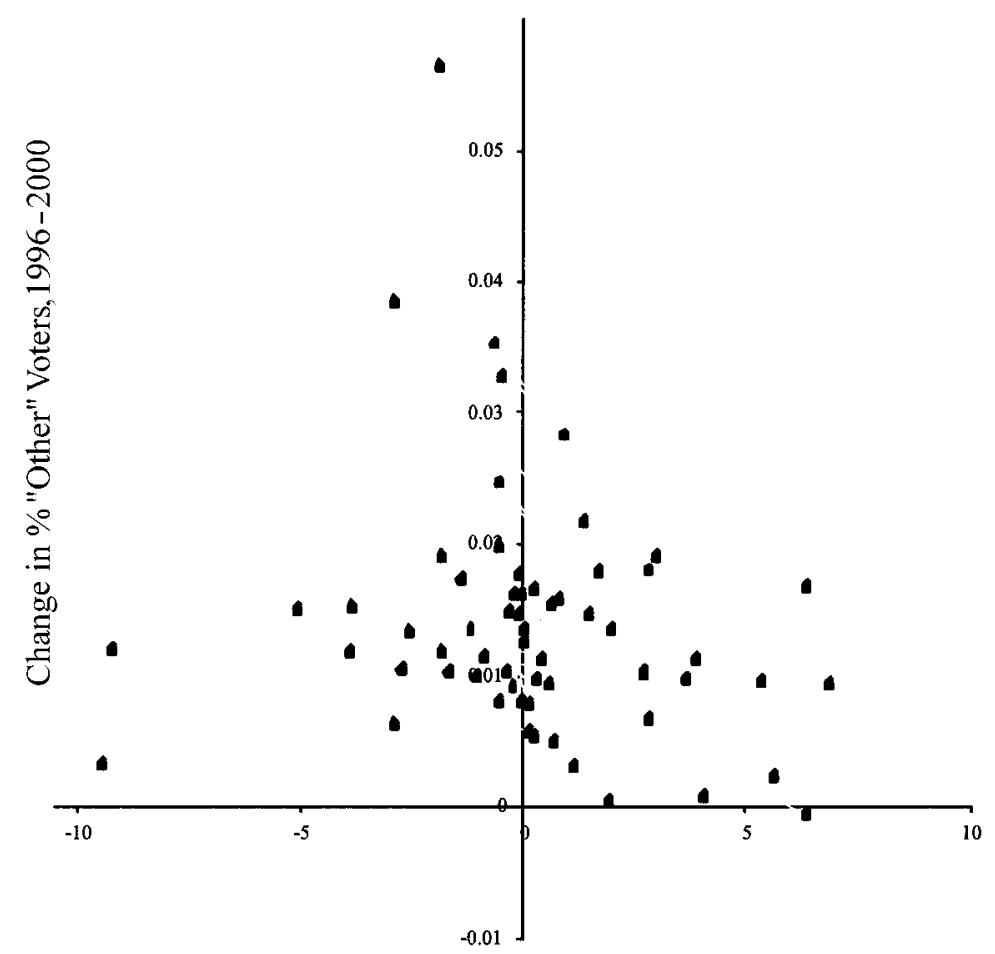

Change in \% Nonvoted Ballots, 1996-2000

Figure 4. "Other" voters and nonvoted ballot rate

only one race-related variable (the number of African Americans in a precinct), implies that adding a thousand more African Americans in a precinct would increase the number of nonvoted ballots by only .25 percent. However, columns 3 and 4 provide some insight into what is being hidden by lumping all African Americans together. Simply disaggregating by political registration between Republicans and Democrats produces one coefficient that is much larger and one that is much smaller than previously shown with the aggregate number. The estimate for African-American Republicans is so large that using columns 1 and 3 implies that 18 African-American Republicans will produce as many nonvoted ballots as 1,000 randomly selected African Americans. For columns 2 and 4, every 15 African-American Republicans produces as many nonvoted ballots as 1,000 randomly selected African Americans. 
While African Americans are registered as Republicans at only about $1 / 18$ th the rate that they register as Democrats, ${ }^{5}$ the results in columns 1-4 imply that African-American Republicans are 54-66 times more likely than the average African American to produce nonvoted ballots.

Another way of saying this last result is that for every two additional black Republicans in the average precinct, there was one additional spoiled ballot. By comparison, it took an additional 125 African Americans (of any party affiliation) in the average precinct to produce the same result.

While illustrative, selectively including only some of the possible racial and ethnic as well as political affiliations of voters creates a problem because the presence of different groupings is likely to be correlated (either positively or negatively) across precincts, and using only select groupings might falsely attribute some of the variation that is in fact associated with other groupings to only those that are included. To deal with this, the rest of the regressions reported in Tables 1 and 2 use all the remaining information of race, ethnic grouping, and political registration that was provided to me by USA Today. In order to avoid perfect collinearity with the variable that measures the number of voters in each precinct, I excluded the variable for voters of "other races registered to other parties (neither Republican nor Democratic)."

Including these other groupings does reduce the size of the coefficient for African-American Republicans, but the coefficients in columns 5 and 6 of Table 1 are still substantial when compared with the average effect for African Americans, with a difference of around 50-55 times. ${ }^{6}$ The bottom third of Table 1 tests to see whether the different voter groups have statistically different effects on the number of nonvoted ballots. What the results show is that African-American Republicans, white Republicans, and Hispanic Republicans have much higher nonvoted ballot rates than African-American Democrats and that all the differences are quite statistically significant. Only for other races is the reverse true, and that difference is very large and also quite statistically significant.

The regressions also allow us to examine whether Bush and Gore voters were different, and here the results are mixed, with the more

5. The data indicate that .5 percent of voters in the average precinct are African Americans registered as Republicans versus 9 percent of voters being African-American Democrats.

6. The 20 counties with the most precincts were also individually examined, and the results showed that this relationship between African-American Republicans and Democrats and nonvoted ballots appeared consistently in counties across the state. 
Table 1. Relationship between Race, Political Affliation, and Party Candidate Voted for and Nonvoted Ballot Rate: Poisson Estimates

\begin{tabular}{|c|c|c|c|c|c|c|}
\hline Selected Exogenous Variables & (1) & (2) & (3) & (4) & (5) & (6) \\
\hline $\begin{array}{l}\text { Number of: } \\
\text { African Americans }\end{array}$ & $\begin{array}{l}1.00038 \\
(23.314)\end{array}$ & $\begin{array}{l}1.00025 \\
(14.863)\end{array}$ & & & & \\
\hline African-American Republicans & & & $\begin{array}{r}1.0206 \\
(44.912)\end{array}$ & $\begin{array}{r}1.0166 \\
(33.456)\end{array}$ & $\begin{array}{l}1.0192 \\
(24.5)\end{array}$ & $\begin{array}{r}1.0138 \\
(16.644)\end{array}$ \\
\hline African-American Democrats & & & $\begin{array}{r}.9999 \\
(-5.627)\end{array}$ & $\begin{array}{r}.9999 \\
(-6.532)\end{array}$ & $\begin{array}{l}1.0016 \\
(4.742)\end{array}$ & $\begin{array}{l}.9963 \\
(-10.61)\end{array}$ \\
\hline African-American independents or third-party members & & & & & $\begin{array}{l}1.0037 \\
(8.332)\end{array}$ & $\begin{array}{c}1.0026 \\
(5.056)\end{array}$ \\
\hline White Republicans & & & & & $\begin{array}{l}1.0029 \\
(6.352)\end{array}$ & $\begin{array}{l}1.0006 \\
(1.306)\end{array}$ \\
\hline White Democrats & & & & & $\begin{array}{l}1.0016 \\
(4.72)\end{array}$ & $\begin{array}{c}.9962 \\
(-10.64)\end{array}$ \\
\hline White independents or third-party members & & & & & $\begin{array}{r}.9993 \\
(-2.311)\end{array}$ & $\begin{array}{l}1.00198 \\
(5.175)\end{array}$ \\
\hline Hispanic Republicans & & & & & $\begin{array}{c}1.003 \\
(7.028)\end{array}$ & $\begin{array}{l}1.00099 \\
(2.106)\end{array}$ \\
\hline Hispanic Democrats & & & & & $\begin{array}{r}1.004 \\
(10.63)\end{array}$ & $\begin{array}{r}.9983 \\
(-4.196)\end{array}$ \\
\hline
\end{tabular}


Hispanic independents or third-party members

\section{Other-race Republicans}

Other-race Democrats

Total voters ("best" estimate)

Bush voters

Gore voters

County-level dummy variables:

Democratic election supervisor

African-American election supervisor

F-statistics:

Nonvoted ballot rate for African-American

Republicans is greater than for

African-American Democrats

Nonvoted ballot rate for white Republicans

is greater than for African-American Democrats

Nonvoted ballot rate for Hispanic Republicans

is greater than for African-American Democrats

Nonvoted ballot rate for Bush voter

is different than for Gore voters ${ }^{b}$

1.00596
$(81.18)$
.99451
$(75.305)$
.99451
$(73.66)$
1.129
$(15.321)$
1.116
$(2.506)$

1.0049
$(60.44)$
.99525

1.0065
$(88.1)$
99,384
$(82.94)$
99,383
$(81.253)$

1.142
$(16.759)$
1.126
$(2.731)$

1.0052
$(64.225)$

$(64.225)$
.99488

(59.52)

.9955

(63.99)

$$
\begin{array}{r}
.9955 \\
(54.499)
\end{array}
$$

.99511

(59.03)

1.142
$(16.759)$
1.126
$(2.731)$

1,087

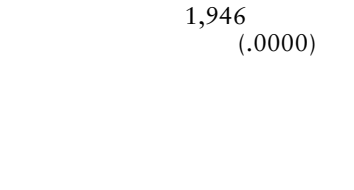

$$
\begin{array}{r}
1,946 \\
(.0000)
\end{array}
$$

$(.0000)$

162.57
$(.0000)$

[Gore]

$(.9568)$

.25

153

(.0000)
.9979
$(-5.363)$

$(-5.363)$
.9951

.9951
$-8.29)$
.9974

(-5.98)

1.006

77.11)

.9945

$64.54)$
.9938

.9938
$(78.77)$

1.137

1.168

(3.544)

398

(.0000)

355.4

$\begin{array}{ll}4.4 & 45.43 \\ (.036) & (.000)\end{array}$

$\begin{array}{lc}6.87 & 53.15 \\ (.0087) & (.0000)\end{array}$

347

139.3

(.0000)

(.0000)
.9994

.9997

1.0049

9.495)

.52)

.99574

$.995)$
.99516

(56.44) 
Table 1. continued

\begin{tabular}{lrrrrrr}
\hline Selected Exogenous Variables & $(1)$ & $(2)$ & $(3)$ & $(4)$ & $(5)$ & $(6)$ \\
\hline County fixed effects & No & Yes & No & Yes & No & Yes \\
Log likelihood & $-35,871$ & $-27,743$ & $-34,991$ & $-27,236$ & $-33,850$ & $-26,818$ \\
$R^{2}$ & .6732 & .7472 & .6812 & .7519 & .6916 & .7557 \\
\hline
\end{tabular}
$R^{2}$

Note. Endogenous variable: uncounted tally. Coefficients are incident rate ratios, so values greater than one indicate the percent increase in uncounted votes from a 1 -unit increase in exogenous variable, while values less than one indicate the opposite. Not all variables are reported below. Dummy variables involved votes counted centrally or at the precinct; different types of voting machines; type of ballot used; income categories from $\$ 15,000$ to $\$ 25,000$ and up through over $\$ 500,000$; and level of schooling from high school not completed through college graduate. Additional variables were the number of males, number of females, number of absentee ballots, number of new voters, mean age, and number of people over 65 . The omitted categories were people earning under $\$ 15,000$, less than ninth-grade education, gender unknown, punch card with chads counted centrally, and neither white, AfricanAmerican, nor Hispanic voters who were neither Republicans nor Democrats. Values in parentheses are $z$-statistics except for $F$-statistics, which include probability values. $N=5,739$.

${ }^{a}$ Recorded here only when county fixed effects are not used.

${ }^{\mathrm{b}}$ The candidate with the larger nonvoted ballot rate is in brackets. 
complete regressions showing that Bush voters had the higher nonvoted ballot rate, with the other two significant results showing the same for Gore. Generally, females have a higher nonvoted ballot rate than males. Higher rates were also observed for older people as well as those living in counties with Democratic and/or African-American county election supervisors. This last effect is quite large. Column 5 in Table 1 indicates that a county with a Democratic supervisor experiences a nonvoted ballot rate that is 14 percent higher, and a county with African-American Democratic supervisor has a rate that is 31 percent higher. $^{7}$

Table 2 uses the final two specifications in Table 1 to break down nonvoted ballots by whether they are "undervotes" (no recorded vote for president) or "overvotes" (multiple recorded votes for president). What this shows is that the impact of having either more African-American Republicans or Democrats has very similar effects on both types of votes. Additional African-American Republicans are associated with both significantly more under- and overvotes, while additional AfricanAmerican Democrats are only statistically significantly related to fewer under- and overvotes when the race and political affiliation of the county election supervisors are not included.

The voting methods and mechanisms are quite important in explaining the nonvoted ballot rate. Punch cards without chads are associated with higher nonvoted ballots in both specifications 5 and 6, although whether the ballots were paper or optical with arrows has the next highest rate depends on the specification. Central processing has a higher nonvoted ballot rate than processing at the precinct, and both the infamous "butterfly" and the " $8-2$ " ballots tend to be associated with more nonvoted ballots. As shown in Table 3, removing information on whether ballots are counted centrally or at the precinct, the ballot type, and the machine type reduces the amount of variation in nonvoted ballots explained by these regressions by 11 percentage points. ${ }^{8}$ (The first row in Table 3 corresponds to column 6 in Table 1.) By contrast, removing measures of race and political affiliation reduce the amount of variation explained by a little over 2 percentage points.

While information on the educational attainment of residents and household income is important in explaining variations in nonvoted ballot rates, the patterns are not easily explained by simply relying on

7. There is only one African-American supervisor, and that person is a Democrat.

8. Cutting out these variables when fixed county effects are included has no discernable impact on the ability to explain the variation across precincts in nonvoted ballots. 
Table 2. Disaggregating Undercounts and Overcounts: Poisson Estimates

\begin{tabular}{|c|c|c|c|c|}
\hline \multirow[b]{2}{*}{ Selected Exogenous Variables } & \multicolumn{2}{|c|}{ Undercount Tally } & \multicolumn{2}{|c|}{ Overcount Tally } \\
\hline & (1) & $(2)$ & (3) & (4) \\
\hline \multicolumn{5}{|l|}{ Number of: } \\
\hline African-American Republicans & $\begin{array}{c}1.0143 \\
(9.508)\end{array}$ & $\begin{array}{l}1.01336 \\
(8.557)\end{array}$ & $\begin{array}{r}1.0196 \\
(20.246)\end{array}$ & $\begin{array}{c}1.01357 \\
(13.301)\end{array}$ \\
\hline African-American Democrats & $\begin{array}{r}.9999 \\
(-.019)\end{array}$ & $\begin{array}{c}.998 \\
(-3.162)\end{array}$ & $\begin{array}{l}1.00016 \\
(.398)\end{array}$ & $\begin{array}{c}.99477 \\
(-12.027)\end{array}$ \\
\hline African-American independents or third-party members & $\begin{array}{l}1.0028 \\
(2.663)\end{array}$ & $\begin{array}{r}1.0065 \\
(5.874)\end{array}$ & $\begin{array}{r}1.0079 \\
(10.249)\end{array}$ & $\begin{array}{l}1.00317 \\
(3.986)\end{array}$ \\
\hline White Republicans & $\begin{array}{l}1.0078 \\
(9.616)\end{array}$ & $\begin{array}{l}1.00462 \\
(5.515)\end{array}$ & $\begin{array}{r}.9996 \\
(-.711)\end{array}$ & $\begin{array}{c}.99679 \\
(-5.382)\end{array}$ \\
\hline White Democrats & $\begin{array}{l}1.0005 \\
(.817)\end{array}$ & $\begin{array}{c}.998627 \\
(-2.144)\end{array}$ & $\begin{array}{c}.99994 \\
(-.155)\end{array}$ & $\begin{array}{r}.99445 \\
(-12.624)\end{array}$ \\
\hline White independents or third-party members & $\begin{array}{r}.9982 \\
(-2.220)\end{array}$ & $\begin{array}{c}1.004 \\
(4.662)\end{array}$ & $\begin{array}{c}1.0038 \\
(5.985)\end{array}$ & $\begin{array}{c}1.0035 \\
(5.321)\end{array}$ \\
\hline Hispanic Republicans & $\begin{array}{l}1.00795 \\
(9.75)\end{array}$ & $\begin{array}{l}1.00458 \\
(5.413)\end{array}$ & $\begin{array}{l}1.00013 \\
(.214)\end{array}$ & $\begin{array}{c}.99732 \\
(-4.439)\end{array}$ \\
\hline Hispanic Democrats & $\begin{array}{l}1.00212 \\
(-2.084)\end{array}$ & $\begin{array}{l}1.00005 \\
(.07)\end{array}$ & $\begin{array}{l}1.00387 \\
(8.131)\end{array}$ & $\begin{array}{r}.99708 \\
(-5.624)\end{array}$ \\
\hline
\end{tabular}


Hispanic independents or third-party members

Other-race Republicans

Other-race Democrats

Total voters ("best" estimate)

Bush voters

Gore voters

County-level dummy variables for the type of election supervisor: ${ }^{2}$

Democratic election supervisor

African-American election supervisor

F-statistic:

Nonvoted ballot rate for African-American Republicans is greater than

for African-American Democrat

Nonvoted ballot rate for white Republicans is greater than for African-American Democrats ${ }^{\mathrm{b}}$

Nonvoted ballot rate for Hispanic Republicans is greater than for African-American Democrats

Nonvoted ballot rate for Bush voters is different than for Gore voters

\begin{tabular}{|c|c|}
\hline .99667 & 1.00243 \\
\hline$(-3.479)$ & $(2.436)$ \\
\hline .98996 & .99996 \\
\hline$(-7.984)$ & $(-.032)$ \\
\hline .99774 & 1.0049 \\
\hline$(-2.084)$ & (4.339) \\
\hline 1.00997 & 1.011 \\
\hline$(74.00)$ & $(77.829)$ \\
\hline .99053 & .98929 \\
\hline$(-67.774)$ & $(-71.584)$ \\
\hline .9897 & .9899 \\
\hline$(-75.715)$ & $(-70.735)$ \\
\hline $\begin{array}{c}1.04929 \\
(3.467) \\
3.3733 \\
(22.72)\end{array}$ & \\
\hline $\begin{array}{l}71.1 \\
\quad(.0000)\end{array}$ & $\begin{array}{l}77.66 \\
(.0000)\end{array}$ \\
\hline $\begin{array}{l}46.52 \\
(.0000)\end{array}$ & $\begin{array}{l}32.51 \\
\quad(.0000)\end{array}$ \\
\hline $\begin{array}{l}48.28 \\
\quad(.0000)\end{array}$ & $\begin{array}{l}48.98 \\
\quad(.0000)\end{array}$ \\
\hline $\begin{array}{c}119.23 \\
(.0000) \\
\text { Bush] }\end{array}$ & $\begin{array}{c}48.14 \\
(.0000) \\
\text { [Gore] }\end{array}$ \\
\hline
\end{tabular}

$$
\begin{gathered}
1.00123 \\
(1.676) \\
1.00206 \\
(2.15) \\
1.00316 \\
(4.125) \\
1.00332 \\
(34.158) \\
.99747 \\
(-24.241) \\
.9965 \\
(-36.178) \\
\\
1.0584 \\
(5.015) \\
.18072 \\
(-11.240)
\end{gathered}
$$

$$
(-11.240)
$$

\subsection{9}

(.0000)

\subsection{5}

(.0000)

0

(.965)

318.32

(.0000)
1.00046

(.604)

1.0038

(3.812)

1.0081

(10.058)

1.0017

(21.691)

$(-11.351)$

.9977

$(-26.489)$

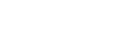

[Bush] 
Table 2. continued

\begin{tabular}{llrrrr}
\hline & \multicolumn{2}{c}{ Undercount Tally } & & \multicolumn{2}{c}{ Overcount Tally } \\
\cline { 2 - 3 } Selected Exogenous Variables & $(1)$ & $(2)$ & & $(3)$ & $(4)$ \\
\hline County fixed effects & No & Yes & & No & Yes \\
Log likelihood & $-18,259$ & $-16,829.6$ & & $-28,413.5$ & $-21,689$ \\
Pseudo $R^{2}$ & & .5717 & .6052 & .6959 & .7679 \\
\hline
\end{tabular}

Note. Coefficients are incident rate ratios, so values greater than one indicate the percent increase in uncounted votes from a 1-unit increase in exogenous variable, while values less than one indicate the opposite. Not all variables are reported below. Other variables include dummy variables involved votes counted centrally or at the precinct; different types of voting machines; type of ballot used; income categories from $\$ 15,000$ to $\$ 25,000$ and up through over $\$ 500,000$; and level of schooling from high school not completed through college graduate. Additional variables were the number of males, number of females, number of absentee ballots, number of new voters, mean age, and number of people over 65 . The omitted categories were people earning under $\$ 15,000$, less than ninth-grade education, gender unknown, punch card with chads counted centrally, and neither white, African-American, nor Hispanic voters who were neither Republicans nor Democrats. Values in parentheses are $z$-statistics except for $F$-statistics, which include probability values. $N=5,631$.

${ }^{a}$ Recorded here only when county fixed effects are not used.

b The exception is column 3 , where the reverse is true.

c The candidate with the larger nonvoted ballot rate is in brackets. 
NONVOTED BALLOTS / 197

Table 3. How Much Can Be Explained Simply by Using Information on Voting Methods and Machines?

\begin{tabular}{lc}
\hline Regression Type & Pseudo- $R^{2}$ \\
\hline All variables including county fixed effects & .7557 \\
All variables excluding county fixed effects & .6916 \\
All variables excluding county fixed effects, & \\
$\quad \begin{array}{l}\text { whether ballots are counted centrally or } \\
\text { at precinct, ballot type, and machine type }\end{array}$ & .5823 \\
All variables excluding county fixed effects & \\
$\quad$ and race and political affiliation measures & .6697 \\
\hline
\end{tabular}

"voter stupidity." The results for Figure 5 vary with whether a separate variable is included to pick up average differences in nonvoted ballots across counties (so-called county fixed effects), but in both cases those who have attended some high school have higher nonvoted ballot rates than those with less than a ninth-grade education. Without county fixed effects, those with some college have a significantly higher nonvoted ballot rate than all but those with some high school.

The relationship between household income and nonvoted ballots in Figure 6 is even more puzzling. No matter what specification is used, there are wide swings in the nonvoted ballot rate for people at the higher income levels, with those whose incomes range between $\$ 250,000$ and $\$ 499,000$ showing unusually lower rates of nonvoted ballots and those above $\$ 500,000$ showing the reverse. Indeed, the nonvoted ballot rate for this top income group is at least 4.6 times higher than that observed for the next highest category (those between $\$ 150,000$ and $\$ 249,999$, another extremely wealthy group of households) and 15 times higher than those in households earning less than $\$ 15,000$ a year. Even over lower ranges of income, it is difficult to detect any obvious pattern.

The education and household income results make it difficult to argue that nonvoted ballots arise from a lack of intelligence. One possibility is that these results arise simply from differences in "tastes." For example, the high nonvoted ballot rate for African-American Republicans could arise simply because they were more conflicted than other voters in deciding whom to vote for. Similar types of conflicted views might be arising for other groups such as those in households making over $\$ 500,000$ or those with some high school education.

As to ballot types and voting machines, having the candidate names listed in one column, optical machines, or paper ballots that are counted by hand, as well as ballots counted at the precinct level, are associated with relatively fewer nonvoted ballots. Both measures of older people 
198 / THE JOURNAL OF LEGAL STUdies / VOLUME 32 (1) / JANUARY 2003

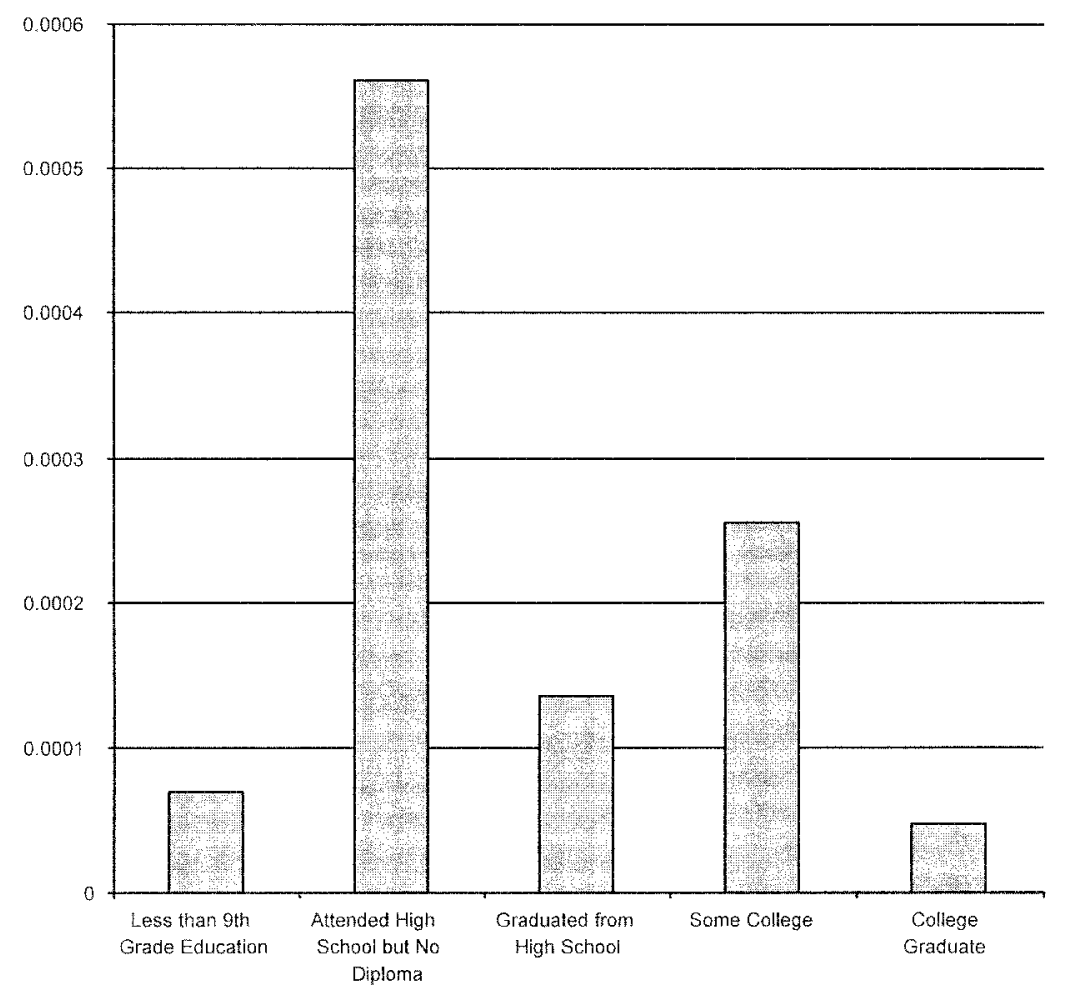

Figure 5. Relationship between educational attainment and nonvoted ballot rate

(the mean adult age and number of people over age 65) are strongly related to more nonvoted ballots.

While a strong case can be made for the inclusion of all the variables included in the data set, there is still the issue of whether the results are dependent on any single variable or set of variables. If one is sure that all the control variables should be included in the regressions, little work is needed beyond Tables 1 and 2. However, on the chance that some might object to the inclusion of certain variables, I have tried to briefly run specifications that first drop out one of the control variables (or closely related set of control variables) and then drop out a second one. A closely related set of variables involves something such as the education, voting machine, ballot type, or gender of voters. I also tried including only one of the control variables (or closely related set of 


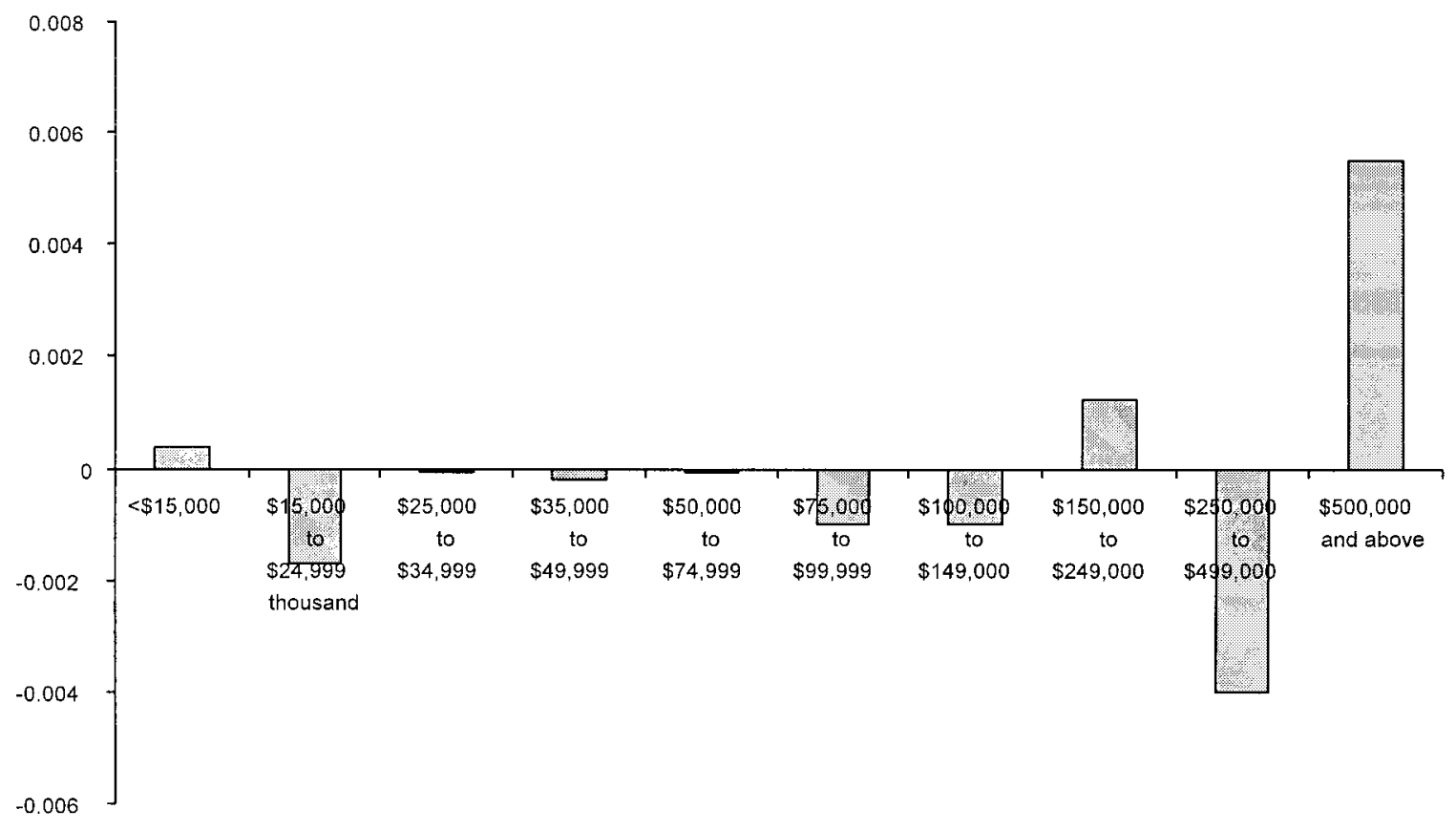

Figure 6. Relationship between income and nonvoted ballot rate 
control variables) at a time. A total of 175 regressions are presented, and they provide fairly consistent estimates.

While about 17 percent of the results from this sensitivity test imply that African-American Democrats may be associated with more nonvoted ballots, even in those relatively rare cases where the relationship is positive, the coefficient is at most about one-tenth as large as the coefficient for African-American Republicans. In every single case white Republicans have a higher nonvoted ballot rate than African-American Democrats, and the difference is always statistically significant at better than the .0004 level (which means that we can reject these differences as being due to randomness at least at the four per 10,000 level). The results reported earlier are thus due to the inclusion of one of the control variables (or sets of control variables) supplied by the newspaper consortium.

Table 4 examines whether different types of voters are systematically affected by the same types of voting machines. The table reports the results in which the race and political affiliation of African-American voters are interacted with the different types of voting machines. The results for the other races and political affiliations were used and are available from the author. If African Americans could be discriminated against through the placing of more troublesome voting machines in precincts where there were more African Americans, one would expect both African-American Republicans and Democrats to be adversely affected by the same type of machine. Yet what is most surprising is that African-American Republicans and Democrats seem to have been so differently affected by the different types of voting machines. Indeed, for only two of the six voting machines is the relationship between African-American Republicans and Democrats the same (optical with ovals and paper/hand machines). These results cast doubt on the nonvoted ballot rate being the result of the use of voting machines per se.

Finally, Table 5 shows that the nonvoted ballot rate for AfricanAmerican Republicans relative to Democrats is actually a couple of times larger for these heavily African-American precincts than it is for all precincts as a whole. Examining only those precincts where over 90 percent of voters are African American and using the regressions in Table 3 shows that the difference is statistically significant at the 10 percent level for five of the six specifications. If something unusual is occurring to African-American ballots in the most heavily African-American precincts, it is precisely in those precincts that the relative impact on AfricanAmerican Republicans is the largest. 
Table 4. Interacting Voting Machine Type and Type of Voter: Poisson Estimates

\begin{tabular}{lcc}
\hline Race, Political Affiliation, and & $\begin{array}{c}\text { Impact on } \\
\text { Uncounted } \\
\text { Votes }\end{array}$ & $\begin{array}{c}\text { Statistical } \\
\text { Significance }^{\mathrm{a}}\end{array}$ \\
\hline African-American Republicans: & & \\
$\quad$ Punch cards with chads & 1.009 & 9.93 \\
Punch cards without chads & .935 & 29.63 \\
Optical with oval & 1.078 & 1171.75 \\
Optical with arrow & .984 & 16.4 \\
Lever & 1.007 & .00 \\
Paper/hand & .009 & .03 \\
African-American Democrats: & & \\
Punch cards with chads & .997 & 7.52 \\
Punch cards without chads & 1.019 & 39.55 \\
Optical with oval & 1.008 & 32.41 \\
Optical with arrow & 1.012 & .00 \\
Lever & .993 & .00 \\
Paper/hand & .071 & \\
African-American others: & & 14.04 \\
Punch cards with chads & 1.007 & 24.61 \\
Punch cards without chads & 1.045 & 48.2 \\
Optical with oval & .984 & 28.87 \\
Optical with arrow & 1.013 & .00 \\
Lever & 1.002 & .03 \\
Paper/hand & .007 & \\
\hline
\end{tabular}

Note. Coefficients are incident rate ratios, so values greater than one indicate the percent increase in uncounted votes from a 1-unit increase in exogenous variable while values less than one indicate the opposite. The same breakdown was used for whites and Hispanics and implied the same inconsistent results across party affiliations. Not all variables are reported below. Other variables include dummy variables involving votes counted centrally or at the precinct; different types of voting machines; type of ballot used; income categories from $\$ 15,000$ to $\$ 25,000$ and up through over $\$ 500,000$; and level of schooling from high school not completed through college graduate. Additional variables were the number of males, number of females, number of absentee ballots, number of new voters, mean age, and number of people over 65 . The omitted categories were people earning under $\$ 15,000$, less than ninth-grade education, gender unknown, punch card with chads counted centrally, and neither white, AfricanAmerican, nor Hispanic voters who were neither Republicans nor Democrats.

${ }^{a}$ Values are $t$-statistics for punch cards with chads and $F$-statistics otherwise. 
Table 5. Disaggregating Undercounts and Overcounts for Precincts Where over 90 Percent of Voters are African American: Poisson Estimates

\begin{tabular}{|c|c|c|c|c|c|c|}
\hline \multirow[b]{2}{*}{ Exogenous Variables } & \multicolumn{2}{|c|}{ Undercount Tally } & \multicolumn{2}{|c|}{ Overcount Tally } & \multicolumn{2}{|c|}{ Total Nonvoted Ballots } \\
\hline & $(1)$ & (2) & (3) & (4) & (5) & (6) \\
\hline Number of African-American Republicans & $\begin{array}{l}1.0564 \\
(3.674)\end{array}$ & $\begin{array}{l}1.043 \\
(2.759)\end{array}$ & $\begin{array}{l}1.013 \\
(1.587)\end{array}$ & $\begin{array}{l}1.0095 \\
(1.068)\end{array}$ & $\begin{array}{l}1.0378 \\
(5.14)\end{array}$ & $\begin{array}{l}1.0202 \\
(2.667)\end{array}$ \\
\hline Number of African-American Democrats & $\begin{array}{r}.9984 \\
(-.411)\end{array}$ & $\begin{array}{l}1.005 \\
(1.222)\end{array}$ & $\begin{array}{r}.9993 \\
(-.355)\end{array}$ & $\begin{array}{r}.9979 \\
(-.951)\end{array}$ & $\begin{aligned} & .9992 \\
&(-.43)\end{aligned}$ & $\begin{array}{r}.9987 \\
(-.653)\end{array}$ \\
\hline $\begin{array}{l}\text { Nonvoted ballot rate for African-American } \\
\text { Republicans is greater than for African- } \\
\text { American Democrats (F-statistic) }\end{array}$ & $\begin{array}{l}13.69 \\
(.0002)\end{array}$ & $\begin{array}{l}5.67 \\
(.017)\end{array}$ & $\begin{array}{l}2.68 \\
(.098)\end{array}$ & $\begin{array}{l}1.66 \\
(.198)\end{array}$ & $\begin{array}{l}26.48 \\
(.0000)\end{array}$ & $\begin{array}{l}7.83 \\
(.0051)\end{array}$ \\
\hline $\begin{array}{l}\text { County fixed effects } \\
\text { Log likelihood } \\
\text { Pseudo } R^{2}\end{array}$ & $\begin{array}{l}\text { No } \\
-701.8 \\
.5551\end{array}$ & $\begin{array}{l}\text { Yes } \\
-659.97 \\
.5816\end{array}$ & $\begin{array}{l}\text { No } \\
-943.8 \\
\quad .8356\end{array}$ & $\begin{array}{l}\text { Yes } \\
-781.3 \\
.8639\end{array}$ & $\begin{array}{l}\text { No } \\
-1116 \\
.8201\end{array}$ & $\begin{array}{r}\text { Yes } \\
-904 \\
8542\end{array}$ \\
\hline
\end{tabular}

Note. Coefficients are incident rate ratios, so values greater than one indicate the percent increase in uncounted votes from a 1-unit increase in exogenous variable, while values less than one indicate the opposite. Not all variables are reported below, though all the variables used earlier are employed here. Values in parentheses are $z$-statistics, except for F-statistics, which include probability values. $N=204$. 


\section{ANALYZING THE COUNTY-LEVEL DATA FOR THE 1992, 1996, AND 2000 PRESIDENTIAL ELECTIONS}

As noted earlier, using purely cross-sectional data faces severe limitations in accounting for differences across counties. Unfortunately, though, the panel-level data limit us to using county-level data. It is also unfortunate that the data for previous years do not allow us to break down voter data by both race and political affiliation. There are many reasons why spoilage rates differ, and accounting for the 46 variables used in our analysis (or the smaller number available in the commission's report; see my Appendix) leaves out many possible factors that are necessary to explain the difference in ballot spoilage rates in different counties. Using information on nonvoted ballot rates during previous presidential elections allows us to examine whether changes in the racial composition of voters can explain changes in these rates. None of my results imply that increasing the share of voters in any racial or ethnic group significantly increases nonvoted ballot rates.

While neither the Florida Secretary of State's Office nor individual county election offices have detailed records on current county-level voting operations, past information was not readily available on some variables, such as the method of voting, where the votes were tabulated, and the race of the county election supervisor. ${ }^{9}$ Fortunately, Election Data Services provides data on the type of voting machine by county for the last three presidential elections. During 1996 and 2000, 14 counties switched from lever machines and 11 counties switched from Datavote machines. Most of the changes for the 1996 election, and all of those for 2000, were toward the adoption of optical scan machines.

In the regressions shown in Table 6, I use only the percentage of the voters by race and not the demographic breakdown of the general population. In place of the median income and poverty rate, I use data that I had readily available on per capita income, per capita unemployment insurance payments, and per capita income maintenance payments (welfare).$^{10}$ These last three variables were available only through 1998 , so I use those values as proxies for the year 2000. County fixed effects are used to account for other factors that explain differences in nonvoted

9. Telephone calls were made to all the individual county election supervisor's offices in an attempt to obtain these data.

10. The data on these income and payment values were obtained from the Regional Economic Information System. Income maintenance includes Supplemental Security Insurance, Aid to Families with Dependent Children, and food stamps. 
Table 6. Using County-Level Data during Presidential Years from 1992 to 2000

\begin{tabular}{|c|c|c|c|c|c|}
\hline & (1) & (2) & (3) & (4) & (5) \\
\hline$\%$ African-American voters & $\begin{array}{c}.343 \\
(1.081)\end{array}$ & $\begin{array}{l}.325 \\
(.951)\end{array}$ & $\begin{array}{c}.661 \\
(1.853)^{+}\end{array}$ & $\begin{array}{c}.192 \\
(1.077)\end{array}$ & \\
\hline$\%$ Hispanic voters & $\begin{array}{c}-.158 \\
(.335)\end{array}$ & $\begin{array}{l}-.323 \\
(.643)\end{array}$ & $\begin{array}{l}.2096 \\
(.364)\end{array}$ & $\begin{array}{l}-.38 \\
(1.411)\end{array}$ & $\begin{array}{c}-.221 \\
(.404)\end{array}$ \\
\hline$\%$ white voters & $\begin{array}{l}.161 \\
(.576)\end{array}$ & $\begin{array}{l}.113 \\
(.39)\end{array}$ & $\begin{array}{l}.2398 \\
(.838)\end{array}$ & & $\begin{array}{l}.211 \\
(.671)\end{array}$ \\
\hline $\begin{array}{l}\% \text { African-American voters } \times \text { : } \\
\text { Republican county election supervisor }\end{array}$ & & & $\begin{array}{c}-.8067 \\
(1.775)^{+}\end{array}$ & & \\
\hline Democratic county election supervisor & & & $\begin{array}{l}-.2259 \\
(2.245)^{*}\end{array}$ & & \\
\hline Dummy for punch card voting equipment & & & & & $\begin{aligned} .4476 \\
(1.243)\end{aligned}$ \\
\hline Dummy for Datavote voting equipment & & & & & $\begin{array}{r}-.0167 \\
(.036)\end{array}$ \\
\hline Dummy for lever voting equipment & & & & & $\begin{array}{l}.248 \\
(.607)\end{array}$ \\
\hline Dummy for paper ballot voting equipment & & & & & $\begin{array}{l}.3191 \\
(.493)\end{array}$ \\
\hline Dummy for optical scan voting equipment & & & & & $\begin{array}{c}.423 \\
(1.151)\end{array}$ \\
\hline Nonpartisan county election supervisor & $\begin{array}{l}4.744 \\
(5.852)^{* *}\end{array}$ & $\begin{array}{l}4.618 \\
(5.447)^{* *}\end{array}$ & $\begin{array}{l}.6872 \\
(.352)\end{array}$ & $\begin{array}{l}4.714 \\
(5.859)^{* * *}\end{array}$ & $\begin{array}{l}4.63 \\
(5.364)^{* *}\end{array}$ \\
\hline Republican county election supervisor & $\begin{array}{l}2.63 \\
(3.050)^{* *}\end{array}$ & $\begin{array}{l}2.56 \\
(2.746)^{* * *}\end{array}$ & $\begin{array}{c}3.8099 \\
(1.551)\end{array}$ & $\begin{array}{l}2.634 \\
(3.072) * *\end{array}$ & $\begin{array}{l}2.271 \\
(2.297)^{*}\end{array}$ \\
\hline
\end{tabular}


Voting equipment dummy:

Datavote

Lever

Optical scan

Per capita income

Per capita unemployment insurance payments

Per capita income maintanence payments

$R^{2}$
Prob $>$

8449

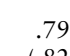

.792
$(.824$
1.276

1.276
$(.709)$

$-1.531$

$(1.774)^{+}$

-.00018
$(1.009)$
$(.0138)$

.0138
$(.453)$
-.0156

$(1.015)$
8488

.0000

.9397

$(1.006$

1.54
$(.881)$

$-1.343$

$(1.598)$

$-.00018$

$(1.052)$

.0208

$(.693)$
-.0198
$(1.291)$

$(1.291)$
.8651

.8651

\begin{tabular}{cc}
.477 & 2.79 \\
$(.528)$ & $(1.307)$ \\
.5332 & 2.681 \\
$(.307)$ & $(1.022)$ \\
-2.007 & -1.623 \\
$(2.464)^{*}$ & $(1.359)$ \\
& -.00017 \\
& $(.931)$ \\
& -.0138 \\
& $(.445)$ \\
& -.0164 \\
.844 & $(1.035)$ \\
.0000 & .8531 \\
& .0000 \\
\hline
\end{tabular}

Note. The endogenous variable is the percent of ballots that are spoiled. Weighted least squares, where the regressions are weighted by the total number of presidential voters in a county, are used because of heterogeneity. Fixed county and year effects are not reported. $N=136$

+ Significant at the $10 \%$ level.

* Significant at the 5\% level.

* Significant at the $1 \%$ level. 
ballot rates across counties, and fixed year effects are used to pick up differences over time. (The literacy rate data could not be included as they were available for only 1 year, and the fixed county effects would be perfectly collinear with this variable. $)^{11}$

The results indicate that the percentage of voters in different race or ethnic categories is rarely statistically related to ballot spoilage. In these specifications, less than 2 percent of the variation in nonvoted ballots is explained by including African-American voters. The only specification that implies a statistically significant relationship between the rate of nonvoted ballots and the percentage of voters who are African American is column 3, but even this result provides little support for the notion that discrimination was occurring. Because the percentage of voters who are African American in column 3 is not only included by itself but is also interacted with whether the county election supervisor is a Republican or a Democrat, the interactions must be added together with the direct effect to determine the net effect of more African-American voters on the nonvoted ballot rate in counties with Republican or Democratic supervisors. Doing this indicates that an increase in the number of African-American voters increases the nonvoted ballot rate when the election supervisors are either nonpartisan or Democrats and decreases the nonvoted ballot rate when they are Republicans. Each 1-percentagepoint increase in the percent of voters who are African American results in the nonvoted ballot rate increasing by .43 percentage points when the election supervisor is a Democrat and decreasing by .15 percentage points with a Republican. The net effects for Democratic or Republican supervisors are not statistically significantly different from zero or from each other. The F-test for the difference between the net impact on African-American voters in counties with Republican or Democratic supervisors is significant at only the 20 percent level. Only the direct effect of the percentage of voters who are African American is really statistically significant, and that is picking up what is happening in counties run by nonpartisan election supervisors.

11. As a proxy for new voters who may have made mistakes because they had not previously voted, I used a variable for the change in the number of voters by race from previous elections. This proxy has definite problems since an increase in the number of voters in a particular racial category can arise from experienced voters moving from one place to another. I found no significant impact from this variable. However, I was unable to determine whether this lack of statistical significance was due to there really not being a problem arising from new voters or from problems with the measure itself. Including these variables did not alter the other findings. 
The last specification replaces the simple variable for the percentage of voters who are African American with that variable being interacted with the dummy variables for the type of voting machines used. It is interesting to note that the coefficient on the interaction for punch card machines is almost identical to the interaction for optical scan machines, and $F$-tests indicate that none of the different voting methods implies a different rate of nonvoted ballots as the percent of voters who are African American increases.

As for the other variables, nonpartisan and Republican county election supervisors are associated with more nonvoted ballots. A county that switches from a Democratic to a nonpartisan election supervisor sees its nonvoted ballot rate more than double. Yet while the average rates are higher for Republicans than Democrats, the nonvoted ballot rate that does exist is more likely to be positively related to the share of voters who are African American in Democratically controlled counties. The average nonvoted ballot rate declined significantly from 1992 to 1996 and then rose very slightly in 2000 . The coefficients for optical scanners always imply a statistically significant lower rate of nonvoted ballots, and three of the five coefficients are statistically significant. None of the other variables produces consistent results.

Table 7 replaces the voting share data in column 1 of Table 6 with census demographic data to measure the differential impact that age, sex, and race might have on nonvoted ballots. ${ }^{12}$ This breakdown was not readily available in terms of those who voted in the elections, so we use the census data as a substitute. One reason for relying on this census data is that when the percentage of African Americans in the general population is used in place of African Americans as a share of voters in the previous regressions, we obtain results that are roughly similar in size and statistical significance.

The results in Table 7 tell a much more complicated story of the relationship between race and nonvoted ballots than is discussed by the commission's report. For five age and sex categories, an increase in the share of voters who are African American implies more nonvoted ballots. Yet for the other five age and sex categories, the reverse is true. It is not clear what form of discrimination would imply that more African-American males between the ages of 30 and 39 would increase the rate of nonvoted ballots, but the reverse is true for African-American females in that age range.

12. These data were obtained from U.S. Department of Commerce (2002). 
Table 7. Examing the Racial and Gender Differences Further Using County-Level Data from 1992 to 2000

\begin{tabular}{|c|c|c|}
\hline Racial and Gender Data (\%) & $\begin{array}{l}\text { Coefficient } \\
\text { Sign }\end{array}$ & $\begin{array}{l}\text { Statistically } \\
\text { Significant?a }\end{array}$ \\
\hline \multicolumn{3}{|l|}{$20-29$ years of age: } \\
\hline African-American male & - & No \\
\hline African-American female & + & No \\
\hline White male & + & No \\
\hline White female & - & No \\
\hline Other male & + & Yes \\
\hline Other female & - & Yes \\
\hline \multicolumn{3}{|l|}{ 30-39 years of age: } \\
\hline African-American male & + & No \\
\hline African-American female & - & No \\
\hline White male & - & No \\
\hline White female & + & No \\
\hline Other male & - & Yes \\
\hline Other female & + & Yes \\
\hline \multicolumn{3}{|l|}{$40-49$ years of age: } \\
\hline African-American male & - & No \\
\hline African-American female & + & No \\
\hline White male & + & No \\
\hline White female & - & No \\
\hline Other male & + & No \\
\hline Other female & - & No \\
\hline \multicolumn{3}{|l|}{$50-64$ years of age: } \\
\hline African-American male & + & No \\
\hline African-American female & - & No \\
\hline White male & - & Yes \\
\hline White female & + & Yes \\
\hline Other male & + & No \\
\hline Other female & - & No \\
\hline \multicolumn{3}{|l|}{ Over 64 years of age: } \\
\hline African-American male & + & No \\
\hline African-American female & - & No \\
\hline White male & - & No \\
\hline White female & + & No \\
\hline Other male & - & Yes \\
\hline Other female & + & Yes \\
\hline
\end{tabular}

Note. The regression corresponds to the estimates reported in column 1 in Table 4. The endogenous variable is the percent of ballots that are spoiled. Weighted least squares are used because of heterogeneity. The only coefficient signs reported here are those for the percentage of the population that fall into a particular age, sex, and race category. $N=199$.

${ }^{a}$ Is the coefficient statistically significant at the 10 percent level for a onetailed $t$-test? 
While the panel data here imply that increasing the number of African Americans in a county does not increase the nonvoted ballot rate, it is still possible that the rate of nonvoted ballots for African-American Republicans is much higher than the rate for African-American Democrats. Yet the inability to break down voter data by both race and political affiliation across these different elections makes it impossible to test this hypothesis with the panel data.

\section{THE EVIDENCE ON EXCLUDING CONVICTED FELONS}

The evidence on convicted felons proves the opposite of what the commission claims. The U.S. Commission on Civil Rights (2001, p. 24) states that "the chance of being placed on this list [the exclusion list] in error is greater for African Americans." The evidence provided indicates that African Americans had a greater share of successful appeals. However, since African Americans also constituted an even greater share of the list to begin with, whites were actually the most likely to be erroneously on the list (a 9.9 percent error rate for whites [125/1,264] versus only a 5.1 percent error rate for blacks $[239 / 4,678])$. The rate for Hispanics (8.7 percent [105/1,208]) is also higher than that for African Americans. The commission's own table thus proves the opposite of what it claims to show. A greater percentage of whites and Hispanics who were placed on the disqualifying list were originally placed there in error.

In any case, this evidence has nothing to do with whether people were in the end improperly prevented from voting, and there is no evidence presented on that point. The commission's evidence examines only those who successfully appealed and says nothing about how many people of those who did not appeal could have successfully done so.

\section{CONCLUSION}

It is difficult to see any evidence that African-American Democrats in Florida were systematically discriminated against in terms of voting. The results clearly indicate that with respect to nonvoted ballot rates, the differences within races are as large as the differences between races. If one believes that African Americans were systematically prevented from voting, it is African-American Republicans who were the most harmed. If one believes that the actions of county election supervisors played an important role in creating this problem (by either intent or carelessness), 
the rate of nonvoted ballots was clearly the highest in counties with Democratic and/or African-American supervisors. As to concerns that the poor were likely to have their ballots not counted, the results decisively reject this conclusion. Not only do voters whose household incomes fall between $\$ 15,000$ and $\$ 24,999$ have a lower nonvoted ballot rate than voters in any income range below $\$ 150,000$ (with the exception of one estimate for the $\$ 75,000$ to $\$ 99,999$ range), but the group with by far the highest nonvoted ballot rate is the very richest, with annual household incomes over $\$ 500,000$. The panel data make it very difficult to ascertain any systematic bias, either intentional or unintentional, against African-American voters.

The results raise the question of why African-American or white Republicans produce more spoiled ballots than African-American Democrats. There are at least two possibilities: (1) certain groups just happened to be more conflicted about whom they were going to choose for president or (2) there was some type of systematic effort to tamper with African-American Republican ballots. One test of the second hypothesis could involve examining how voters voted for other offices on the same ballot. For example, if African-American Republicans had problems with all the races for which they did not vote for the Democrat, it could raise questions of tampering. Unfortunately, USA Today did not collect these data. In any event, the level of conspiracy to systematically perform this tampering across the entire state would appear to be very difficult to keep quiet, and there is no additional evidence that this type of tampering took place. These results on race as well as those shown on education and income levels seem to lend more credence to the view that groups of voters were just more conflicted about whom to vote for.

\section{APPENDIX: USING THE MAJORITY REPORT'S COUNTY-LEVEL DATA}

Given the U.S. Commission on Civil Rights (2001, chap. 1) emphasis on "intentional discrimination," it seems useful to try to account for those involved in the process who might have some reason for either discriminating against African-American voters or preventing such discrimination. Some obvious controls for this are the political party affiliation or race of the county election supervisor. If the suspected discrimination is occurring against African Americans and given that African Americans vote so heavily for Democrats, it seems doubtful that Democratic or African-American election supervisors would act in ways to increase the rate of nonvoted ballots of African Americans. 
Using the cross-sectional evidence preferred by the Commission on Civil Rights, Appendix Table A4 provides some preliminary information that casts doubt on whether Republicans are responsible for the problems with nonvoted ballots. Indeed, the counties with Democratic election supervisors have the highest nonvoted ballot rate, with white Democrat supervisors having a higher rate than African-American Democrat supervisors. White Republican election supervisors have the lowest rate of spoiled ballots; indeed, the nonvoted ballot rate for white Republican supervisors is only a third of the rate of black Democratic supervisors. Comparison of the top and bottom halves of Table A4 also shows why cross-sectional analysis produces a simple correlation between race and nonvoted ballots. Those counties with the highest rates of African-American voters also were more likely to have both Democratic supervisors and more spoiled ballots.

Since the commission's report, which was presented to the Senate, shows exactly what regression specifications were examined, I tried different specifications to replicate the commission's results. The results (available from the author) showed that the simple cross-sectional county-level data were very sensitive to the specification used and that most specifications failed to show any statistically significant positive relationship between the percentage of voters who were African American and the nonvoted ballot rate. Thus, when the commission's very own set of control variables is used, there is thus no real confidence that there is a positive relationship between the share of African-American voters and the ballot spoilage rate. 


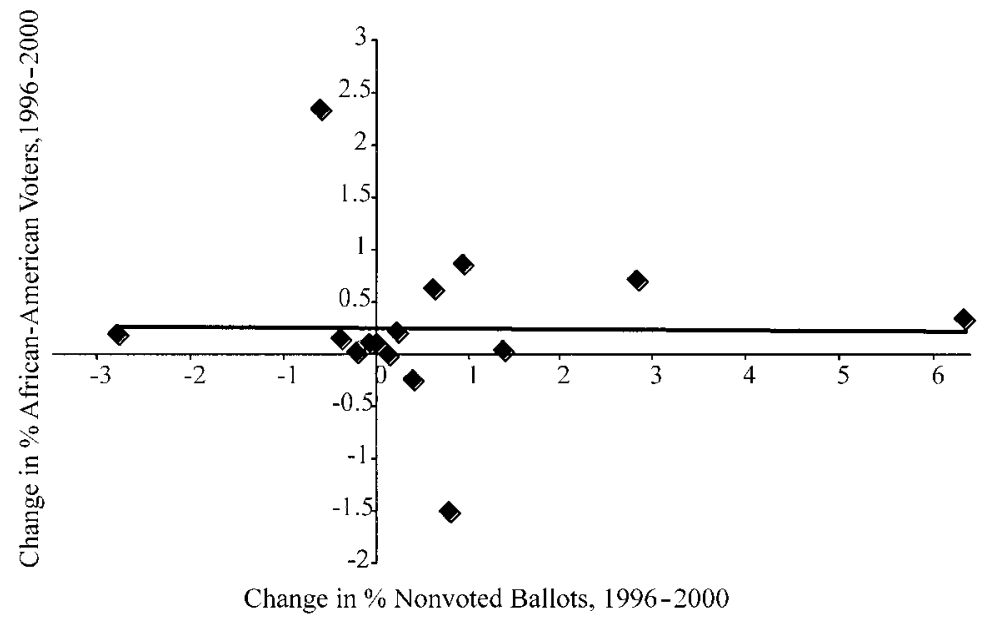

Figure A1. Counties using punch card machines in both elections-African Americans

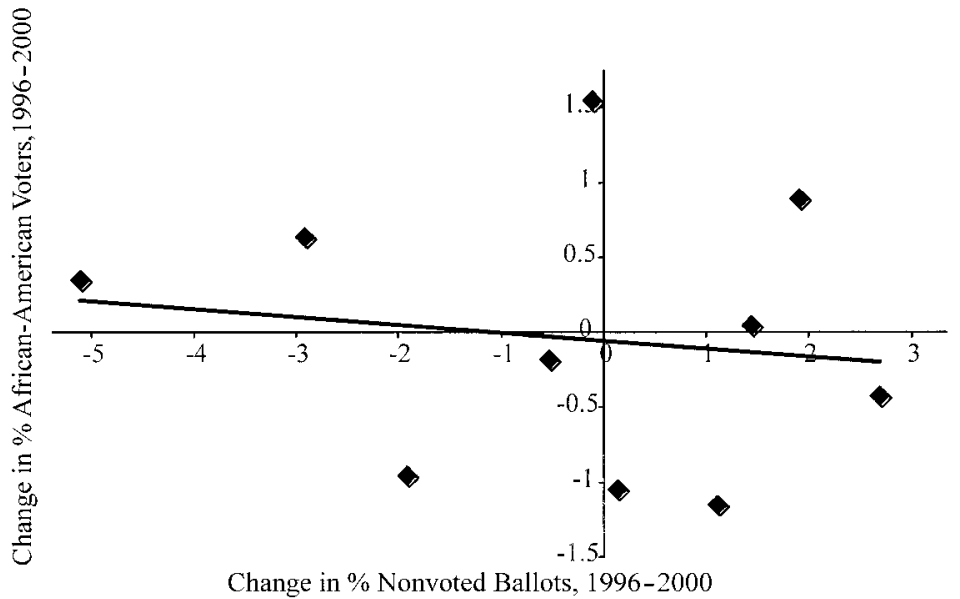

Figure A2. Counties using Datavote machines in both elections-African Americans 


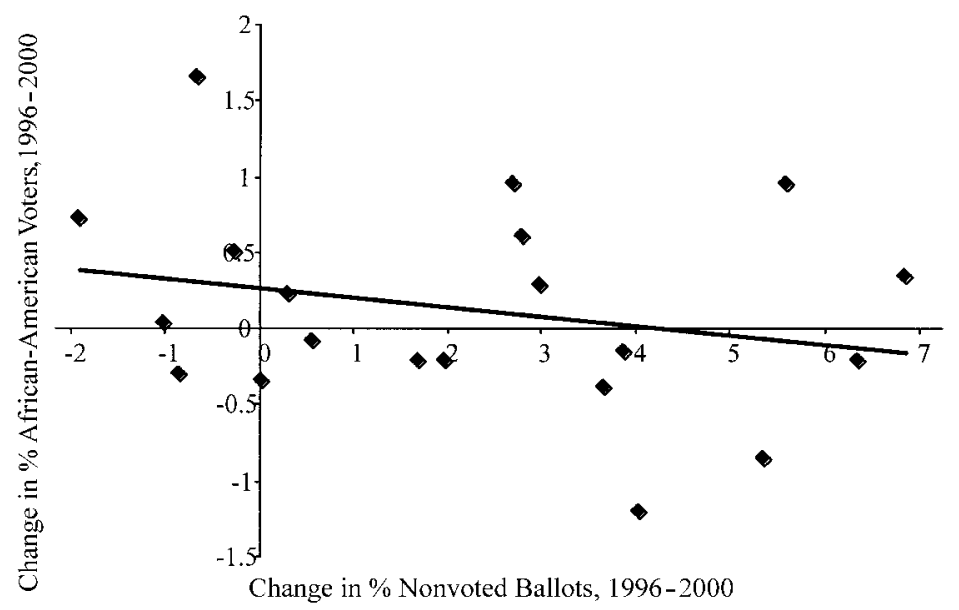

Figure A3. Counties using optical scan machines in both elections-African Americans

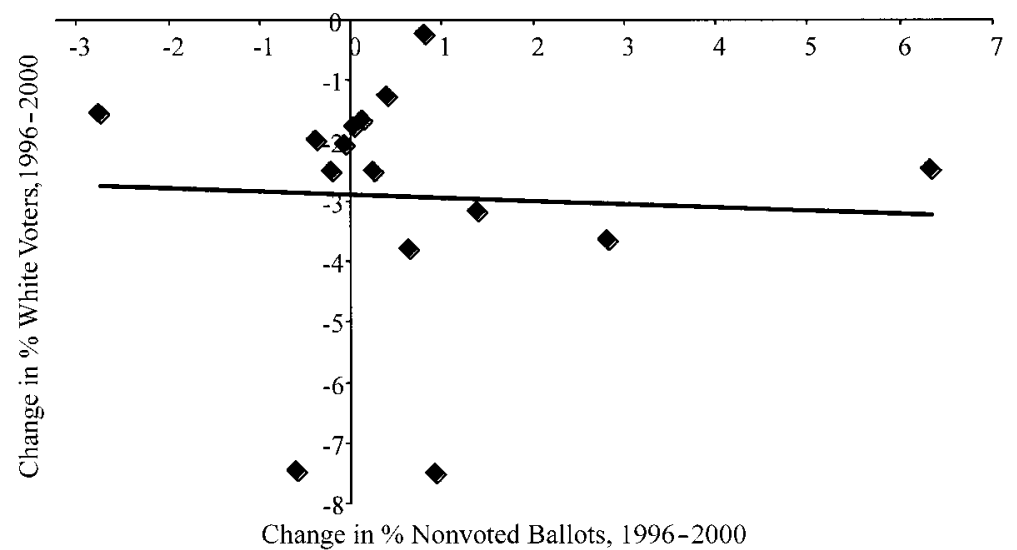

Figure A4. Counties using punch card machines in both elections-whites 


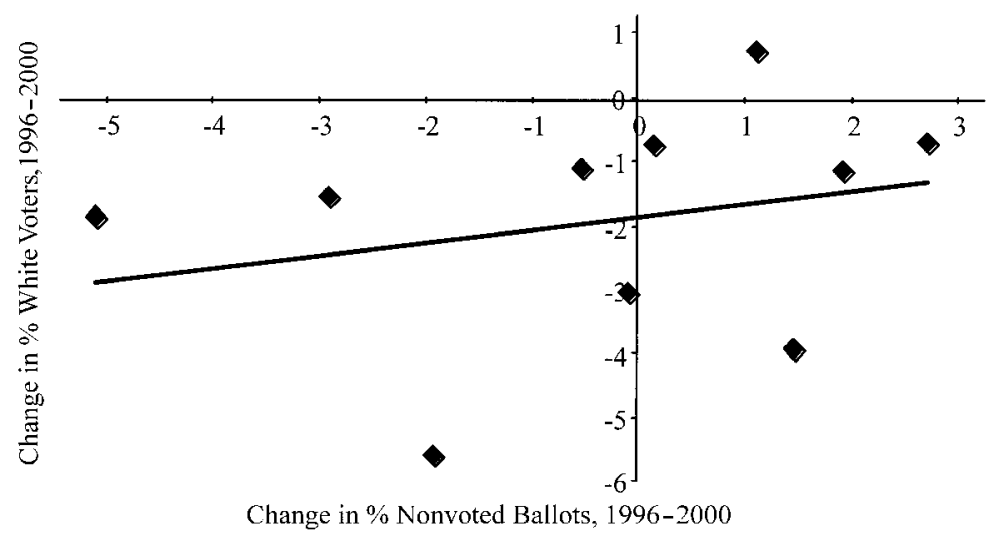

Figure A5. Counties using Datavote machines in both elections-whites

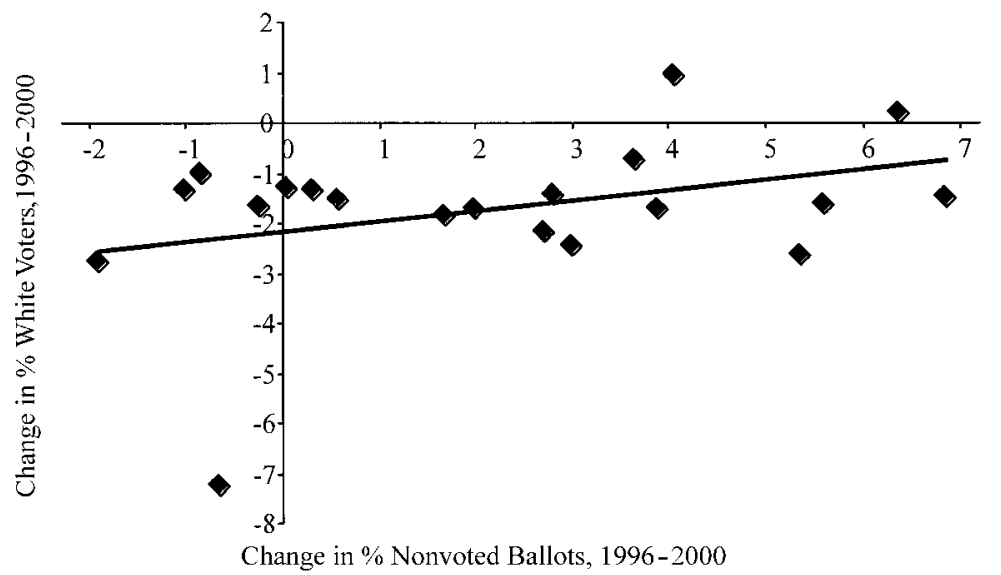

Figure A6. Counties using optical scan machines in both elections-whites 


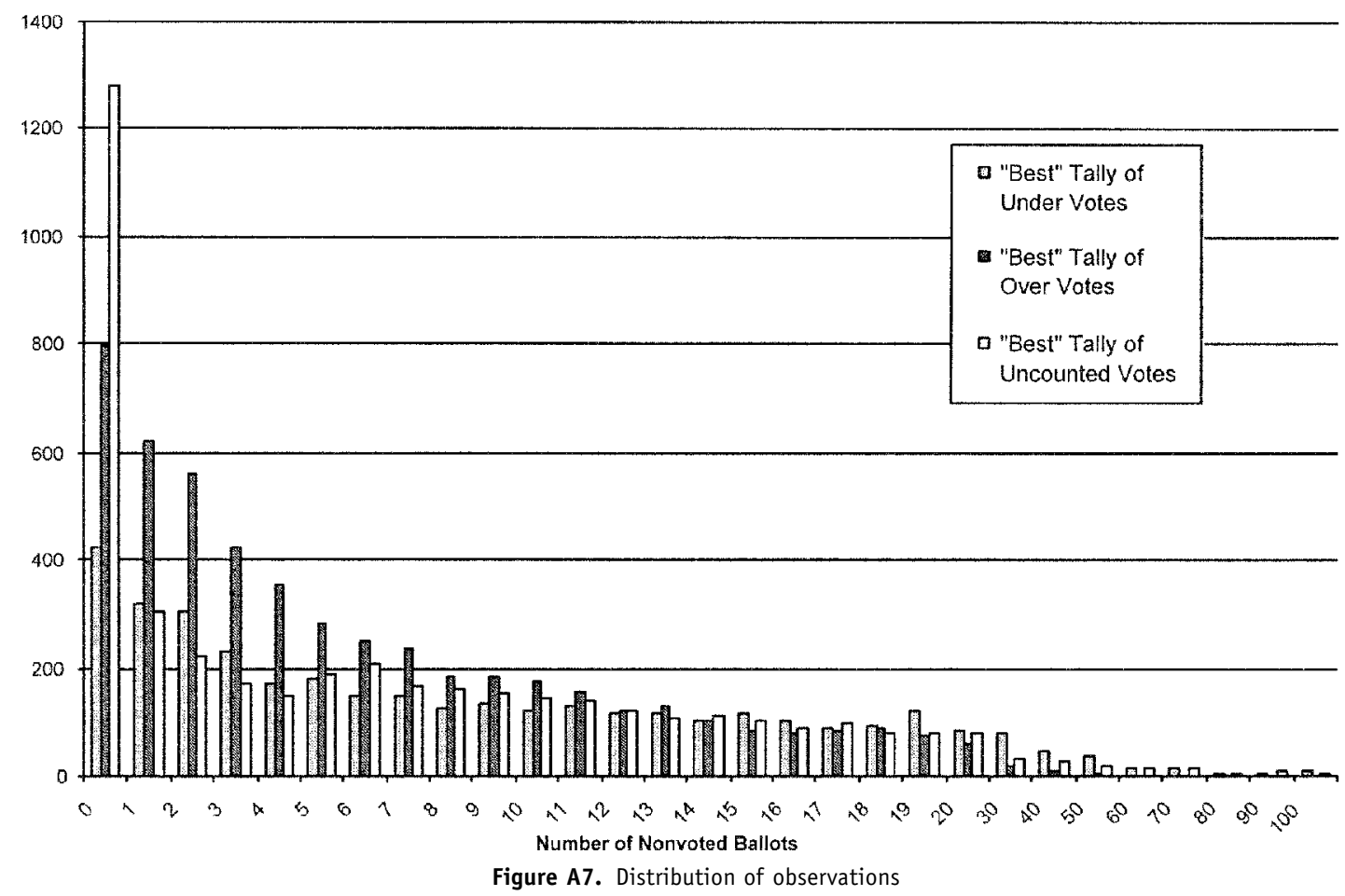


Table A1. Precinct Cross-Sectional Data

\begin{tabular}{|c|c|c|c|c|}
\hline Variable & Mean & $\begin{array}{l}\text { Standard } \\
\text { Deviation }\end{array}$ & Min & $\operatorname{Max}$ \\
\hline \multicolumn{5}{|l|}{$\%$ of voters $(N=5,815):$} \\
\hline White & 735.34 & 551.2017 & 0 & 4,240 \\
\hline African American & 97.958 & 196.2034 & 0 & 1,959 \\
\hline Other race & 33.199 & 35.35334 & 0 & 843 \\
\hline Hispanic & 72.243 & 204.7526 & 0 & 2,549 \\
\hline \multicolumn{5}{|l|}{$\begin{array}{l}\text { Number of voters by race and party } \\
\qquad(N=5,815) \text { : }\end{array}$} \\
\hline White Republicans & 332.45 & 297.6515 & 0 & 2,243 \\
\hline White Democrats & 297.513 & 221.881 & 0 & 1,941 \\
\hline \multicolumn{5}{|l|}{ White independents or third-party } \\
\hline African-American Republicans & 3.8298 & 6.394757 & 0 & 58 \\
\hline African-American Democrats & 86.919 & 180.1781 & 0 & 1,813 \\
\hline \multicolumn{5}{|l|}{ African-American independents } \\
\hline Hispanic Republicans & 35.909 & 128.8997 & 0 & 1,841 \\
\hline Hispanic Democrats & 21.747 & 47.16606 & 0 & 490 \\
\hline $\begin{array}{l}\text { Hispanic independents or third- } \\
\text { party members }\end{array}$ & 14.588 & 37.30828 & 0 & 442 \\
\hline \multicolumn{5}{|l|}{$\begin{array}{l}\text { Number of voters by gender } \\
\qquad(N=5,815) \text { : }\end{array}$} \\
\hline Males & 416.64 & 263.8099 & 0 & 2,531 \\
\hline Females & 517.42 & 313.3403 & 0 & 2,846 \\
\hline Unknown & 4.6765 & 6.963052 & 0 & 208 \\
\hline \multicolumn{5}{|l|}{$\begin{array}{l}\text { Number of voters by education level } \\
\qquad(N=5,814) \text { : }\end{array}$} \\
\hline Less than ninth-grade education & 159.307 & 231.4853 & .03 & $3,725.7$ \\
\hline Some high school education & 275.866 & 284.7844 & .1 & $4,171.59$ \\
\hline Graduated from high school & 534.442 & 522.7859 & .17 & $7,892.95$ \\
\hline Some college education & 469.265 & 476.7318 & .09 & $6,670.18$ \\
\hline Graduated from college & 335.03 & 392.3077 & .05 & $5,421.22$ \\
\hline \multicolumn{5}{|l|}{$\begin{array}{l}\text { Number of adults by household } \\
\text { income }(N=5,814) \text { : }\end{array}$} \\
\hline Less than $\$ 15,000$ & 165.069 & 185.4892 & .06 & $2,609.43$ \\
\hline$\$ 15,000-\$ 24,999$ & 151.666 & 153.9805 & .05 & $2,536.39$ \\
\hline$\$ 25,000-\$ 34,999$ & 145.971 & 146.36 & .05 & $2,245.02$ \\
\hline$\$ 35,000-\$ 49,999$ & 175.122 & 175.4718 & .06 & $2,588.12$ \\
\hline$\$ 50,000-\$ 74,999$ & 188.291 & 195.2891 & .05 & $2,872.29$ \\
\hline$\$ 75,000-\$ 99,999$ & 85.152 & 97.65628 & .02 & $1,296.69$ \\
\hline$\$ 100,000-\$ 149,999$ & 54.95 & 73.36145 & 0 & $1,158.85$ \\
\hline$\$ 150,000-\$ 249,999$ & 25.795 & 42.41607 & 0 & 764.04 \\
\hline$\$ 250,000-\$ 499,999$ & 8.845 & 16.10889 & 0 & 238.52 \\
\hline Over $\$ 500,000$ & 4.6333 & 11.14299 & 0 & 197.68 \\
\hline \multicolumn{5}{|l|}{ Number of: } \\
\hline Bush voters $(N=5,799)$ & 432.37 & 347.7245 & 0 & 2,666 \\
\hline Gore voters $(N=5,799)$ & 455.35 & 299.9227 & 0 & 2,967 \\
\hline Undervotes $(N=5,707)$ & 9.0273 & 12.83895 & 0 & 200 \\
\hline Overvotes $(N=5,707)$ & 18.37 & 28.31868 & 0 & 401 \\
\hline Nonvoted ballots $(N=5,815)$ & 27.69 & 35.63885 & 0 & 417 \\
\hline
\end{tabular}


Table A1. continued

\begin{tabular}{lcccc}
\hline Variable & Mean & $\begin{array}{c}\text { Standard } \\
\text { Deviation }\end{array}$ & Min & Max \\
\hline Dummy variable $(N=5,860):$ & & & & \\
$\quad$ Candidates listed in straight line & .808 & .3938907 & 0 & 1 \\
$\quad$ Candidates listed in 8-2 ballot & .0456 & .2085535 & 0 & 1 \\
Candidates listed in 9-1 ballot & .0043 & .0651823 & 0 & 1 \\
Butterfly ballot & .0881 & .2833985 & 0 & 1 \\
Two-page ballot & .0457 & .208925 & 0 & 1 \\
Counted centrally & .1036 & .3047456 & 0 & 1 \\
Counted at precinct level & .276 & .4470241 & 0 & 1 \\
Punch cards with chads & .5846 & .4928258 & 0 & 1 \\
Punch cards without chads & .0179 & .1326651 & 0 & 1 \\
Optical with ovals & .283 & .450628 & 0 & 1 \\
Optical with arrows & .097 & .2961178 & 0 & 1 \\
Lever machines & .0068 & .0823438 & 0 & 1 \\
$\quad$ Paper counted by hand & .0019 & .0432889 & 0 & 1 \\
Number of absentee ballots & & & & 3,497 \\
$\quad(N=5,815)$ & 99.34 & 116.9331 & 0 & \\
Number of voters registered since & & & & 1,276 \\
$\quad$ primary $(N$ = 5,761) & 72.15 & 67.74891 & 1 & \\
\hline
\end{tabular}

Table A2. Description of Variables Used in Cross-Sectional Time-Series Data

\begin{tabular}{|c|c|c|c|c|}
\hline Variable & Mean & $\begin{array}{l}\text { Standard } \\
\text { Deviation }\end{array}$ & Min & $\operatorname{Max}$ \\
\hline$\%$ nonvoted ballots ${ }^{\mathrm{a}}$ & 3.641642 & 3.00916 & 0 & 19.08 \\
\hline \multicolumn{5}{|l|}{$\begin{array}{l}\text { Data omitted from the commission's } \\
\text { report }(N=201) \text { : }\end{array}$} \\
\hline \multicolumn{5}{|l|}{ Election supervisor: } \\
\hline Democrat & .73134 & .44437 & 0 & 1 \\
\hline Nonpartisan & .03015 & .17143 & 0 & 1 \\
\hline Republican & .23116 & .422635 & 0 & 1 \\
\hline \multicolumn{5}{|l|}{$\%$ of voters who are African } \\
\hline $\begin{array}{l}\text { American } \times \text { Democratic } \\
\text { county election supervisor } \\
(N=150) \text { : }\end{array}$ & 7.186407 & 919716 & 0 & \\
\hline \multicolumn{5}{|l|}{$\begin{array}{l}\text { Florida Secretary of State's Office } \\
\text { data: }\end{array}$} \\
\hline \multicolumn{5}{|l|}{ Voter race $(\%)$ : } \\
\hline African American $(N=138)$ & 9.476006 & 8.629639 & .86225 & 51.41108 \\
\hline Hispanic $(N=137)$ & 2.054501 & 5.755577 & 019414 & 45.54942 \\
\hline White $(N=138)$ & 86.56636 & 10.98606 & 30.96044 & 97.85489 \\
\hline \multicolumn{5}{|l|}{$\begin{array}{l}\text { Voting machine data from the } \\
\text { Election Data Service: }\end{array}$} \\
\hline Punch card & .5025 & .5012 & 0 & 1 \\
\hline Datavote & .2637 & .4417 & 0 & 1 \\
\hline Lever & .1045 & .3066 & 0 & 1 \\
\hline Paper ballot & .0199 & 1400 & 0 & 1 \\
\hline Optical scan & .3433 & .4760 & 0 & 1 \\
\hline Electronic & .00995 & .0995 & 0 & 1 \\
\hline
\end{tabular}

a Through either not voting for a candidate or voting for too many candidates for president. 
Table A3. Description of Variables Included in the U.S. Commission on Civil Rights Report, Appendix 1

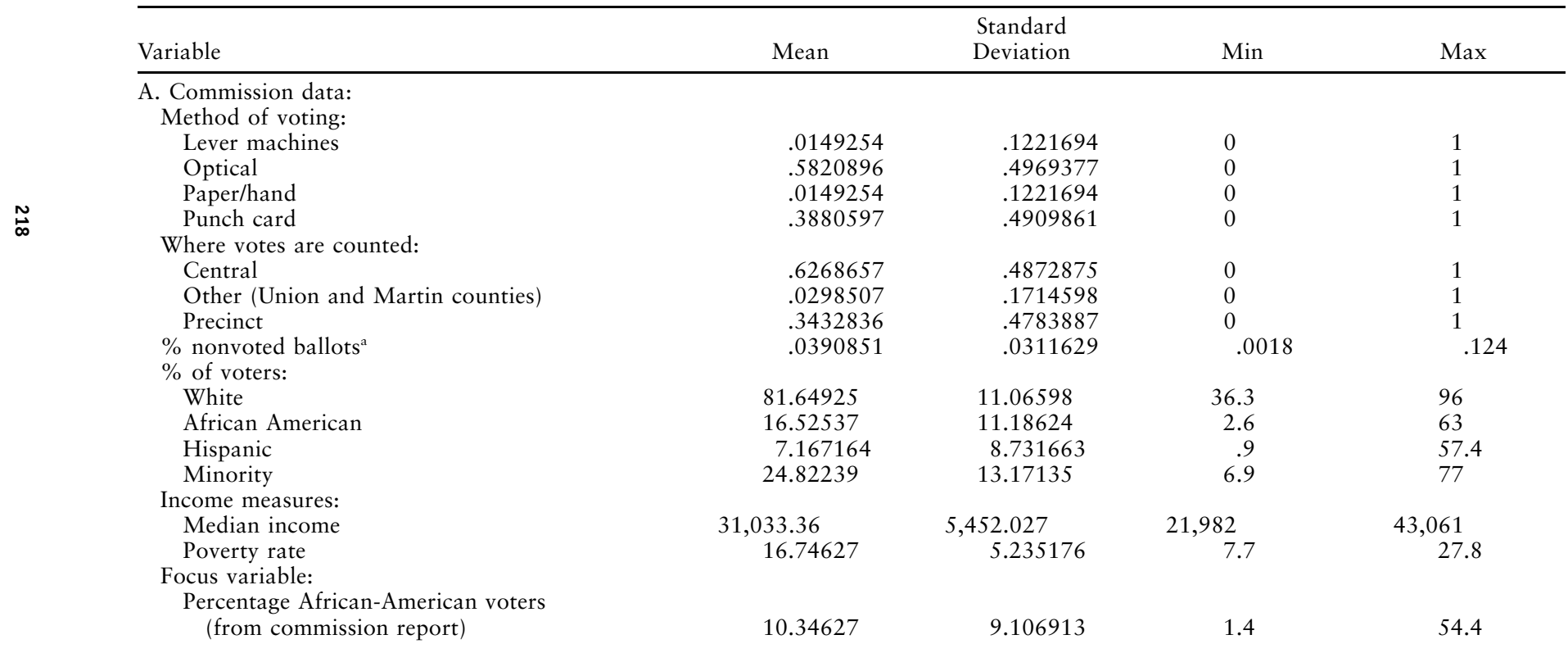


B. Data omitted from the commission's report:

Election supervisor:

African American

Democrat

Nonpartisan

Republican

$\%$ African-American voters $\times$ African-America

county election supervisor

county election supervisor $x$

$\%$ African-American voters $\times$ Democratic county

election supervisor

Florida Secretary of State's Office data:

Percentage of voters:

African American

Hispanic

$\begin{array}{lclc}.0597015 & .2387212 & 0 & 1 \\ .6865672 & .4673898 & 0 & 1 \\ .0447761 & .2083729 & 0 & 1 \\ .26865 & .4466064 & 0 & 1 \\ 1.019403 & 6.761685 & 0 & 54.4 \\ & & & 54.4 \\ 8.253731 & 9.911492 & 0 & \\ & & & 51.41108 \\ 9.54846 & 8.713725 & 1.303079 & 45.54942 \\ 2.451787 & 6.059622 & .0387 & 97.02997 \\ 85.32495 & 11.32964 & 30.96044 & \end{array}$


Table A4. What Types of Counties Had the Highest Nonvoted Ballot Rates (by Percent)?

\begin{tabular}{lccc}
\hline & $\begin{array}{c}\text { Democratic } \\
\text { Election } \\
\text { Supervisor }\end{array}$ & $\begin{array}{c}\text { Republican } \\
\text { Election } \\
\text { Supervisor }\end{array}$ & $\begin{array}{c}\text { Nonpartisan } \\
\text { Election } \\
\text { Supervisor }\end{array}$ \\
\hline $\begin{array}{c}\text { Nonvoted ballots by race and } \\
\text { political affiliation of county } \\
\text { election supervisors (\%): }\end{array}$ & & & \\
$\begin{array}{c}\text { African-American } \\
\text { election supervisor }\end{array}$ & 4.55 & $\ldots$ & $\ldots$ \\
$\begin{array}{c}\text { Non-African-American } \\
\text { election supervisor }\end{array}$ & 4.80 & 1.52 & 4.62 \\
$\begin{array}{c}\text { African-American voters by race } \\
\text { and political affiliation of } \\
\text { county election supervisors (\%): }\end{array}$ & & & \\
$\begin{array}{c}\text { African-American } \\
\text { election supervisor }\end{array}$ & 22.80 & $\ldots$. & $\ldots$ \\
$\begin{array}{c}\text { Non-African-American } \\
\text { election supervisor }\end{array}$ & 11.30 & 4.97 & 16.90 \\
\hline
\end{tabular}

\section{REFERENCES}

Chafets, Zev. 2001. Florida Got Bad Rap in Vote Mess. New York Daily News, June 10.

Hume, Brit. 2001. Special Report with Brit Hume. Fox News Network, June 27.

Thernstrom, Abigail, and Russell G. Redenbaugh. 2001. The Florida Election Report: Dissenting Statement. Washington, DC: U.S. Commission on Civil Rights, July 19. http://www.manhattan-institute.org/final_dissent.pdf.

U.S. Commission on Civil Rights. 2001. Voting Irregularities in Florida during the 2000 Presidential Election. Washington, DC: U.S. Commission on Civil Rights, June 8. http://www.usccr.gov (see Voting Publications).

U.S. Department of Commerce. Bureau of the Census. 2002. Intercensal Estimates of the Population of Counties by Age, Sex, and Race (United States). http://eire.census.gov/popest/archives/1990.php\#county. 